\title{
The Role of Fluids in Promoting Seismic Activity in Active Spreading Centers of the Salton Trough, California, USA
}

\author{
Musa Hussein, Aaron A. Velasco, Laura Serpa, Diane Doser \\ Department of Geological Sciences, University of Texas at El Paso, El Paso, USA \\ Email: mjhussein@utep.edu
}

Received January 26, 2012; revised February 21, 2012; accepted March 14, 2012

\begin{abstract}
We interpret seismic activity in the active spreading centers of the Salton Trough to indicate 1) a magmatic intrusion in the lower crust beneath the active Brawly, Cerro Prieto, Imperial, Elsinore, and San Jacinto fault systems; and 2) fluids in the upper crust that have been released from that magmatic body. The absence of a magmatic body and fluids at the location of fossil spreading centers along the Sand Hill and Algodones faults ndicated by little or no seismic activity in those areas. We show several lines of evidence to point out that both melt and fluids related to the seismic activity. In particular, receiver function analysis, $V p / V s$ ratios, and tomographic data reveal low velocity zones coincide with the location of the active spreading centers. High $V p / V s$ ratios and low velocity zones in the lower crust and upper mantle attributed to melt inclusion, while low $V p / V s$ ratios in the upper crust are attributed water inclusions. Frequency-magnitude distributions characterized by high $b$-values in southern California; high $b$-values have also been associated with crustal fluids. A crustal scale model developed from the receiver functions, gravity, and magnetic data supports the existence of a magmatic intrusion within about $20 \mathrm{~km}$ of the surface southwest of the Salton Sea, that intrusion extends for $70 \mathrm{~km}$ in a SW-NE direction.
\end{abstract}

Keywords: Crustal Model; Magmatic Intrusion; Salton Trough; Seismic Activity; Spreading Centers

\section{Introduction}

Mantle fluids have been interpreted to be associated with the San Andreas fault system in central and southern California [1]. The most promising source of mantle derived fluids comes from mantle wedge material, which was potentially hydrated and serpentinized during subduction prior to the formation of the San Andreas fault and which would subsequently dehydrate after the plate boundary along California transitioned from subduction to strike slip tectonics [2]. Fluids appear to enter the brittle fault zone at or near lithostatic pressure and thus may contribute to fault weakening because of high fluid pressure at seismogenic depths $[3,4]$. Seismicity and tomography suggest that for seismic events to occur in the lower crust, fluids as well as a rheologically strong lower crustal layer must be present in order to restrict the rise of fluids. There has been little consideration of whether ponded magma and exsolved fluids at the base of the crust could similarly trigger lower crustal events [5]. One of the few studies to point out that high pore pressure would be necessary to trigger such lower crustal events has been that of [6], who studied lower crustal earthquakes in the East African Rift and found no difference in rupture characteristics between upper and lower crustal events (based on
$m_{b}-\mathrm{M}_{w}$ relation). This suggests that similar fluid triggering processes may occur throughout the crust as proposed by [5].

In this study, we examine the relationship between fluids and seismicity in active spreading centers (Brawly, Cerro Prieto, Imperial, Elsinore, and San Jacinto) of the Salton Trough and compare those areas with areas of little or no earthquake activity in nearby fossil spreading centers (Sand Hill and Algodones). We used data from the southern California broadband seismic network and data collected by the EarthScope US Array seismic deployment for our analysis. We also obtained data from existing gravity databases at the University of Texas, El Paso (UTEP) (http://www.research.utep.edu/paces)-Pan American Center of Earth and Environmental Studies(PACES) that is currently hosted at the CYBER-ShARE Center of Excellence at UTEP. Aeromagnetic data were obtained from the US Geological Survey. The results of this study indicate a magmatic intrusion at a depth of about $20 \mathrm{~km}$ to the southwest of Salton Sea. That intrusion extends for $70 \mathrm{~km}$ in SW-NE direction.

\section{Tectonic Setting}

The Salton Trough (Figures 1 and 2) is a highly extended terrane at the northern extent of sea-floor spread- 


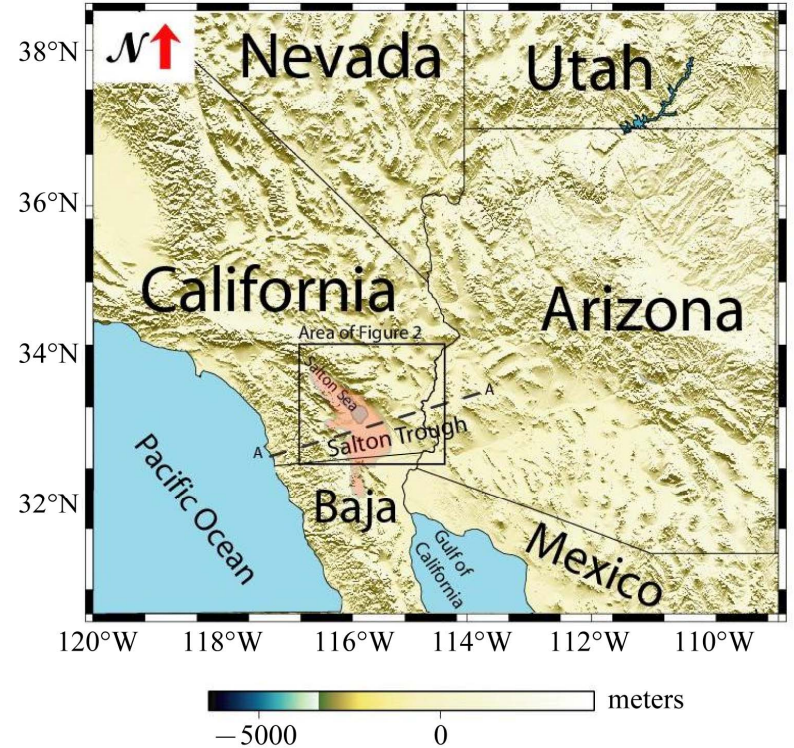

Figure 1. Location map showing the study area and adjacent areas. Dashed line A-A' showing the location of our model. Square box showing the area of Figure 2.

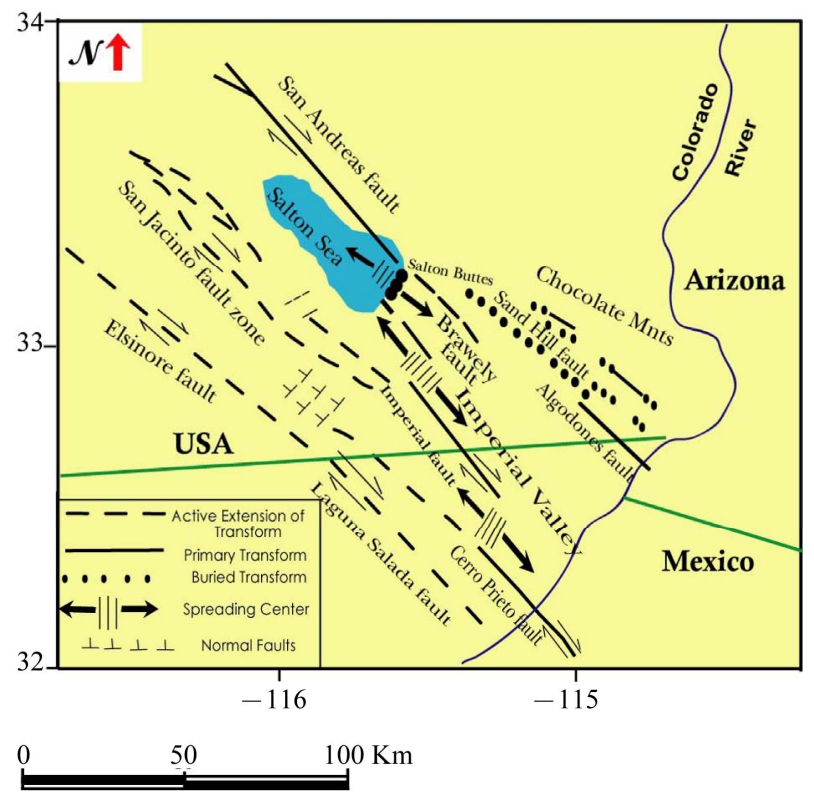

Figure 2. Topographic and structural map of the Salton Trough showing the active spreading centers (gray polygon), and fossil spreading centers (After Lonsdale, 1989).

ing in the Gulf of California [7]. The area has high heat flow and inferred to be in the early stages of transitioning from continental crust to oceanic crust [8].

The Salton Trough results from northward progression of California [8-10]. The initial opening of the Gulf of California occurred about 12 - $10 \mathrm{Ma}$, shortly after subduction ceased along the continental margin of Mexico $[9,11]$. The Salton Trough apparently represents a present day onshore analog to theses Gulf of California evolving spreading centers [10].

The Salton Trough region is seismically active [12] with most of the seismicity in the region occurring along the Imperial and Brawley fault zones (Figure 2, [8]). The Cerro Prieto, Imperial, Brawley, and San Andreas faults form an echelon series of east-stepping, right lateral faults linked by pull apart basins referred to as the Cerro Prieto, Brawley, and Salton Buttes (Figure 2) spreading centers by [10]. These spreading centers have probably changed position more than once. Thus, for example, the parallel Sand Hills and Algodones faults inferred to represent fossil transforms or spreading centers parallel to, but approximately $45 \mathrm{~km}$ east of the Imperial fault zone $[9,13]$.

The Imperial Valley-Salton Trough is highly active seismically [8]. Large earthquakes have occurred on Imperial fault in 1940 (Ms 7.1) and in 1979 (Ms 6.9). Reference [8] suggested based on geodetic, seismic, and heat flow data that the imperial and Brawley fault systems are young (3000 to 100,000 years old) and have migrated northwest into Imperial Valley. The southern most part of the active San Andreas fault extends northwest from the southeast corner of the Saton Trough [12]. Further northeast, smaller Late Cenozoic strike slip faults also known from surface exposure and these likely represent parts of the evolving transform system [7]. We suppose it is possible to classify The Cerro Prieto, Imperial, Brawley, and San Andreas as seisomogenic fault based on the seismic activity along these faults.

\section{Data and Data Analysis}

\subsection{Receiver Functions}

A receiver function is the seismic response of the earth beneath a seismic station to an incoming $P$-wave. In particular, a receiver function maps $P$-to- $S$ converted energy due to impedance contrasts (i.e., changes in velocity and density) in the earth. First-order information about the crustal structure can be derived from the radial receiver function, which is dominated by $P$-to- $S$ converted energy from velocity discontinuities in the crust and upper mantle [14]. Receiver functions can be used to determine crustal thickness, $V p / V s$ ratios, and the lateral variation of the crustal thickness [15]. In receiver function estimation, the foundation of the iterative deconvolution approach is least squares minimization of the difference between the observed horizontal component seismogram and predicted signal generated by convolution of an iteratively updated spike train with the vertical component seismogram [16]. The iterative time-domain approach has several advantages, such as the ability to estimate the percent fit and the long period stability by a priori constructing the deconvolution as a sum of Gaussian pulses [16]. We compute receiver functions using the iterative time deconvolution with Gaussian width $(\mathrm{Ga})$ factors of 2.5 , 
1.75 , and 1 which is equivalent to applying low pass filters with cutoff frequencies of $1.2,0.9$, and $0.5 \mathrm{~Hz}$, respectively.

We collected data from 27 broadband seismograph stations (listed in Table 1 and shown in Figures 3 and $\mathbf{4}$ ) in the vicinity of the Salton Trough, which recorded data from 2000 to 2009.

Specifically, we collected broadband seismic waveform data for teleseismic earthquakes with $M>5.5$. Our approach of analysis consist of several steps, the first step is copying receiver function for stations into different directories, stepping through each year and 100 day Julian day increment. Loop over Julian days 000, 100, 200,300 for each $K(0,1,2,3)$.

Data available directly from the Incorporated Research Institutes for Seismology (IRIS), Data Management Center (DMC), using the Standing Order of Data (SOD), which allowed for automated rotation of the horizontal components to radial and transverse directions. From the waveform data, we computed the radial and transverse receiver functions using iterative deconvolution, keeping data with an $80 \%$ or greater fit. We also manually inspected each radial receiver function to ensure quality. We then stacked the radial receiver functions using the approach of [15]. For stacking we ran the $H-K$ stacking codes, we set the weight to be $(0.3 / 0.5 / 0.2)(0.4 / 0.3 / 0.3)$ and $(0.5 / 0.4 / 0.1)$.

The time separation between $P s$ and $P$ can be used to estimate crustal thickness $H$, given the average crustal velocities of $V s$ and $V p$ :

$$
H=\left(t_{p s}\right) /\left[\sqrt{\left(1 / V s^{2}-p^{2}\right)}-\sqrt{\left(1 / V p^{2}-p^{2}\right)}\right]
$$

where $p$ is the ray parameter of the incident wave [15]. Of concern is the trade-off between the crustal thickness and crustal velocities, since $t_{P S}$ represents the differential

Table 1. Stations codes, coordinates, estimated $V p / V s$, crustal thickness and number of receiver functions used in this study.

\begin{tabular}{|c|c|c|c|c|c|c|}
\hline No. & Station Code & Longitudes & Latitudes & Est. $V p / V s$ & Est. Crustal Thickness & No. of RF \\
\hline 1 & Cl-ADO & -117.43 & 34.55 & $1.74 \pm 0.01$ & $36.49 \pm 0.32$ & 168 \\
\hline 2 & Cl-BBR & -116.92 & 34.26 & $1.95 \pm 0.10$ & $29.00 \pm 0.34$ & 205 \\
\hline 3 & $\mathrm{Cl}-\mathrm{BC} 3$ & -115.45 & 33.66 & $1.80 \pm 0.11$ & $25.50 \pm 0.32$ & 216 \\
\hline 4 & Cl-BEL & -116.00 & 34.00 & $1.76 \pm 0.12$ & $28.59 \pm 0.12$ & 245 \\
\hline 5 & Cl-BFS & -117.66 & 34.24 & $1.81 \pm 0.10$ & $31.00 \pm 0.33$ & 202 \\
\hline 6 & Cl-DAN & -115.38 & 34.63 & $1.69 \pm 0.08$ & $28.03 \pm 0.28$ & 411 \\
\hline 7 & Cl-DVT & -116.10 & 32.66 & $2.07 \pm 0.11$ & $20.50 \pm 0.58$ & 18 \\
\hline 8 & Cl-GLA & -114.83 & 33.05 & $1.67 \pm 0.12$ & $27.00 \pm 0.38$ & 493 \\
\hline 9 & Cl-HEC & -116.34 & 34.83 & $1.79 \pm 0.09$ & $28.44 \pm 0.27$ & 260 \\
\hline 10 & Cl-IRM & -115.15 & 34.16 & $1.80 \pm 0.10$ & $2.00 \pm 0.33$ & 239 \\
\hline 11 & Cl-NEE & -114.60 & 34.82 & $1.87 \pm 0.11$ & $25.96 \pm 0.38$ & 27 \\
\hline 12 & Cl-PDM & -114.14 & 34.30 & $1.73 \pm 0.10$ & $27.96 \pm 0.32$ & 230 \\
\hline 13 & Cl-RRX & -117.00 & 34.86 & $1.88 \pm 0.10$ & $30.49 \pm 0.33$ & 253 \\
\hline 14 & Cl-SWS & -115.80 & 32.94 & $1.61 \pm 0.09$ & $27.96 \pm 0.27$ & 166 \\
\hline 15 & Cl-GMR & -115.66 & 34.78 & $1.77 \pm 0.11$ & $26.57 \pm 0.42$ & 147 \\
\hline 16 & Cl-MUR & -117.20 & 33.60 & $1.77 \pm 0.09$ & $31.15 \pm 0.30$ & 171 \\
\hline 17 & TA-109C & -117.11 & 32.89 & $1.64 \pm 0.11$ & $38.56 \pm 0.34$ & 30 \\
\hline 18 & TA-112A & -114.58 & 32.54 & $1.79 \pm 0.08$ & $25.06 \pm 0.46$ & 29 \\
\hline 19 & TA-Y12C & -114.52 & 33.75 & $1.63 \pm 0.09$ & $33.49 \pm 0.25$ & 83 \\
\hline 20 & TA-W13A & -113.90 & 35.10 & $1.77 \pm 0.09$ & $28.91 \pm 0.30$ & 54 \\
\hline 21 & TA-X13A & -113.80 & 34.60 & $1.76 \pm 0.09$ & $26.98 \pm 0.35$ & 65 \\
\hline 22 & TA-Y13A & -113.83 & 33.81 & $1.72 \pm 0.12$ & $30.4 \pm 0.35$ & 73 \\
\hline 23 & NR-NE70 & -115.26 & 32.42 & $2.35 \pm 0.06$ & $30.48 \pm 0.21$ & 8 \\
\hline 24 & NR-NE71 & -115.91 & 31.69 & $1.83 \pm 0.10$ & $32.50 \pm 0.38$ & 136 \\
\hline 25 & NR-NE72 & -116.06 & 30.85 & $1.85 \pm 0.10$ & $32.10 \pm 0.33$ & 34 \\
\hline 26 & AZ-MONP & -116.42 & 32.89 & $1.78 \pm 0.09$ & $30.49 \pm 0.26$ & 249 \\
\hline 27 & AZ-PFO & -116.46 & 33.61 & $1.81 \pm 0.11$ & $27.05 \pm 0.38$ & 419 \\
\hline
\end{tabular}




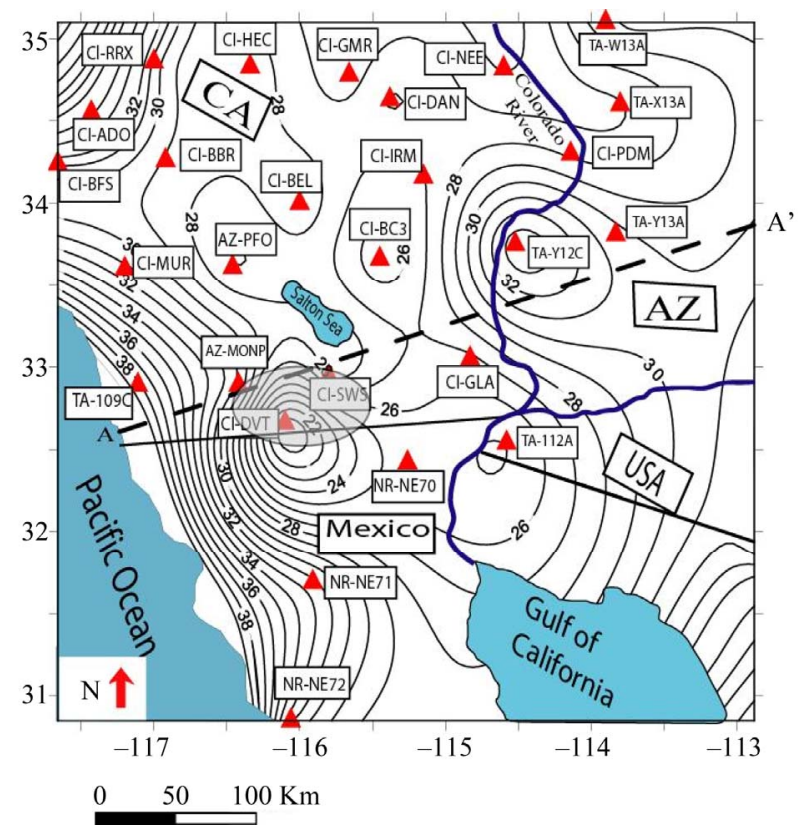

Figure 3. Contour map of the Moho depth (crustal thickness) in $\mathbf{~ k m}$ based on receiver function data. Data were collected from 27 stations (shown as red triangles). Stations codes are shown inside small squares beside each station.

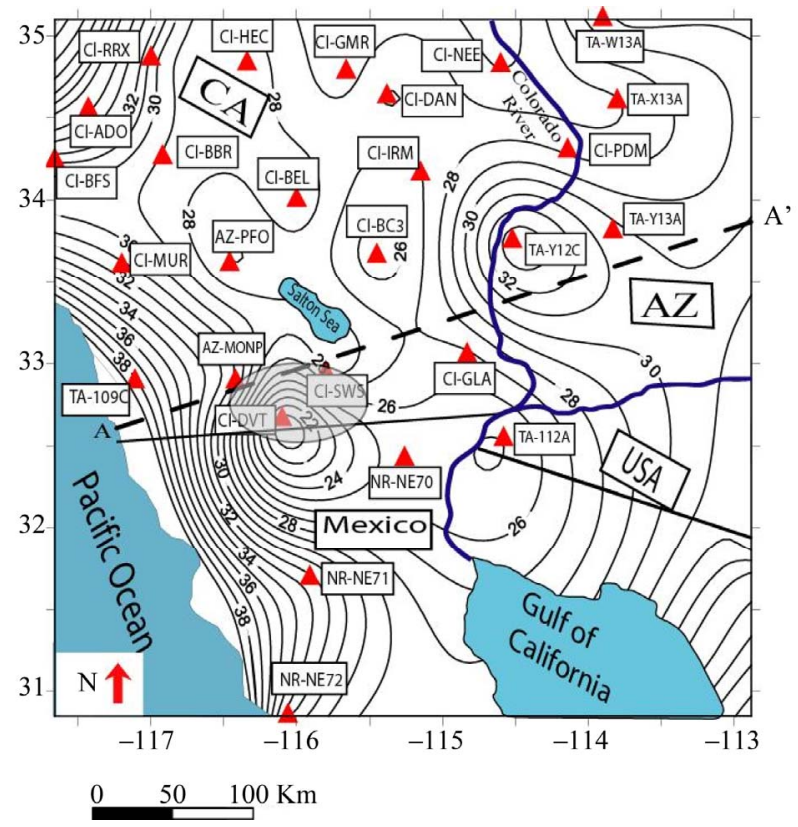

Figure 4. $V p / V$ s contour map, high $V p / V s$ located to the south and southwest of the Salton Sea. Gray circle shows an approximate location of the magmatic intrusion.

travel time of $S$ with respect to $P$ in the crust.

In our analysis, we ran script to calculate the ray parameters for all events and stations in the study area.

The dependence of $H$ on $V p$ is not as strong as the dependence on $V s$ or more precisely on the $V p / V s$ ratio $K$. For example using a $V p$ of $6.3 \mathrm{~km} / \mathrm{s}$ and $V p / V s$ ratio of
1.732 for $30 \mathrm{~km}$ thick crust, one gets:

$$
\Delta H=(\partial H / \partial V p) \Delta V p=4.3 \Delta V p(\mathrm{~km})
$$

which means that the uncertainty of $H$ is $<0.5 \mathrm{~km}$ for a $0.1 \mathrm{~km} / \mathrm{s}$ in $V p$. However, the thickness is highly dependent on the $V p / V s$ as shown by:

$$
\Delta H=(\partial H / \partial V p) \Delta k=-40.2 \Delta k(\mathrm{~km})
$$

i.e., a 0.1 change in $k$ can lead to about $4 \mathrm{~km}$ change in the crustal thickness. This ambiguity reduced by using later phase, which provide additional constraints:

$$
H=\left(t_{P p S s+P_{S P} s}\right) /\left[2 \sqrt{\left(1 / V s^{2}-p^{2}\right)}\right]
$$

so that both $K$ and $H$ can be estimated [17-19].

We contour the crustal thickness and $V p / V s$ ratios (Figures 3 and 4 respectively) using a minimum-curvature algorithm to interpolate values to a rectangular grid. Moho dome shape beneath the area of active upper crust extension suggested being primarily the product of magmatic activity in the lower crust and upper mantle following the interpretation of [20] for a similar feature in Death Valley, California.

Reference [20] suggests that the doming of the lower crust of Death Valley accommodated by the addition of magma to the lower crust.

The Moho is about $20 \mathrm{~km}$ deep southwest of the Salton Sea and increases to $32 \mathrm{~km}$ east of the Salton Sea. The average $V p / V s$ ratio is 1.80 in the study area in general; this ratio increases to the south and southeast of the Salton Sea becoming 2.1 and 2.3, and decreases to the east to 1.6. Reference [21] concluded that high concentration of high $V p / V s$ ratio might be caused by the plagioclase rich mafic composition of the lower crust; because high crustal $S$-wave and Rayleigh wave phase velocity in the same area exclude the possibility of crustal fluids or partial melting as a possible reason for high $V p / V s$. Reference [22] concluded that the low velocity with low $V p / V s$ zones in the upper crust are caused by the inclusion of $\mathrm{H}_{2} \mathrm{O}$ and that low velocity with high $V p / V S$ zones in the lower crust and uppermost mantle are caused by melt inclusions. Magnetotelluric survey in similar areas revealed conductive zones located at a depth of below $15-20 \mathrm{~km}$; this is consistent with the low velocity with high $V p / V s$ zone [23]. Reference [23] inferred that the low velocity anomaly could be explained by the partially molten rock.

\subsection{Frequency-Magnitude Distribution (b-Values)}

The $b$-value is a critical parameter for seismic hazard assessment and an indicator of the presence of fluids and/ or partial melt. The earthquake distributions (number of events vs magnitude) typically follow a power law; and the negative slope of that plot is the $b$-value [24]. Normal 
fault events have the highest $(b)$ values $(b \approx 1.1)$, thrust events the lowest $(b \approx 0.7)$ and strike slip events intermediate values $(b \approx 0.9)$ [24].

Southern California Earthquake Data Center (http://www.data.scec.org/index.html) seismic activity record shows numerous seismic events for September, 2009, that are focused along the San Jacinto, Elsinore, Cerro Prieto and Imperial faults, while seismic activity is weak or absent along the fossil spreading centers of the Sand Hill and Algodones faults (Figure 5). Reference [25] analyzed earthquakes from the local catalog of events in the Southern California region from 07/01/1944 to 03/01/1990 using magnitudes between $M=4.1$ and $M=$ 7.7. The cumulative and the binned density are shown in Figure 6. Slopes in Figure 6 are negative. This observation may imply the number of normal fault events falls off more rapidly with increasing magnitude than is the case for strike-slip or thrust events. $b$-values for the complete catalog are shown in Table 2 . The cumulative distribution seems to have the property of self-similarity across the entire range of magnitude to about $M=6.6$ (Figure 6; from [25]). Reference [26] shows the relation between the depth and the $b$-values in southern California (Table 3).

They separate the data into five depth ranges from 0 3, $3-6,6-9,9-12$, and $12-15 \mathrm{~km}$ for calculating $b$-values, they restricted the magnitude to larger than $M=$ 2.0 for detection and completeness and smaller than $M=$ 5.5. Table 3 shows a decrease in $b$-values with increasing earthquake depth, with exception for the intervals 9 $12 \mathrm{~km}$ and 12 - 15 where the $b$-value is increasing by a very small portion.

Reference [27] showed that areas of high $b$-values from $1.3 \pm 0.05$ up to $1.5 \pm 0.05$ could be attributed to the

Table 2. "b-Values" for complete catalog (After Knopoff, 2000).

\begin{tabular}{ccc}
\hline $\begin{array}{c}\text { Magnitude } \\
\text { Range }\end{array}$ & $\begin{array}{c}\text { " } b \text {-Value" Total Catalogue } \\
\text { (Main and after shocks) }\end{array}$ & $\begin{array}{c}\text { " } b \text {-Value" } \\
\text { Main Shocks }\end{array}$ \\
\hline $4.1-7.7$ & $0.97 \pm 0.03$ & $0.87 \pm 0.05$ \\
$4.1-6.6$ & $0.96 \pm 0.03$ & $0.88 \pm 0.05$ \\
$4.1-4.8$ & $0.98 \pm 0.07$ & $0.99 \pm 0.12$ \\
\hline
\end{tabular}

Table 3. Relation between depth and “b-Values” (After Mori and Abercrombie, 1997).

\begin{tabular}{ccc}
\hline Magnitude Range & Depth $(\mathrm{km})$ & " $b$-Value" \\
\hline $2.0-5.0$ & $0-3$ & $1.026 \pm 0.008$ \\
$2.0-5.0$ & $3-6$ & $1.063 \pm 0.010$ \\
$2.0-5.0$ & $6-9$ & $0.967 \pm 0.016$ \\
$2.0-5.0$ & $9-12$ & $0.923 \pm 0.016$ \\
$2.0-5.0$ & $12-15$ & $0.928 \pm 0.021$ \\
\hline
\end{tabular}

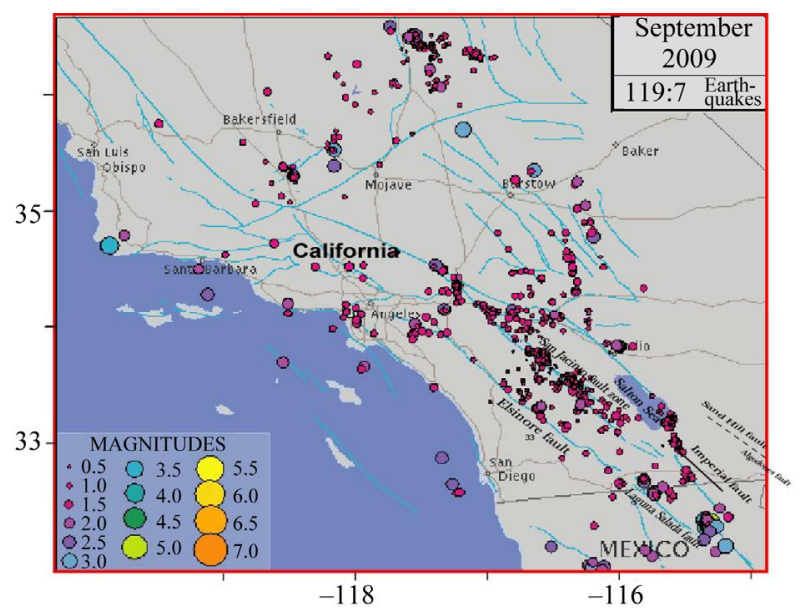

Figure 5. The seismic map of September 2009. Seismic activity focused along the active spreading centers and absent along the fossil spreading centers (Map from Southern California Earthquake Data Center).

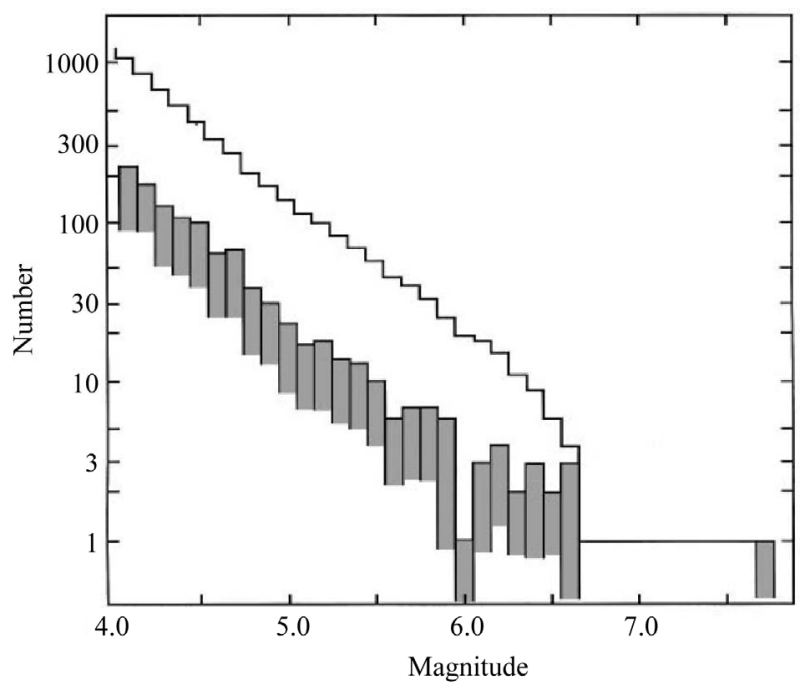

Figure 6. Cumulative and differentiated (shaded) distribution of the magnitudes of all earthquakes in Southern California region from 7-1-1944 to 3-1-1990 (After Knopoff).

presence of high thermal gradients due to the emplacement of magmatic fluids. As magmatic fluids injected into the system and temperatures expected to rise around the intrusion and the crust would weaken due to its inability to accumulate high amounts of stress. The high temperature, weaken crust and expanding sill could cause the formation of numerous small fractures [27].

A relatively large number of smaller earthquakes is expected to accompany the formation of small fractures and would alter the frequency-magnitude distribution of earthquake toward higher $b$-values because of developing deviatoric tension [27].

Reference [28] plotted b-values in Koyna-Warna region, India, and concluded that a systematic increase in $b$-values from $8 \mathrm{~km}$ depth to $12 \mathrm{~km}$ for Koyna earth- 
quakes indicates the presence of pore fluids at a depth greater than $8 \mathrm{~km}$, and stated that low $b$-value areas at 5 $\mathrm{km}$ depth show localized high stresses that are favorable for future rupture.

\subsection{Gravity and Aeromagnetic Data}

We obtained gravity data from UTEP-PACES

(http://www.research.utep.edu/paces) website that is currently hosted at the Cyber-ShARE Center of Excellence at UTEP. We used 40,784 Bouguer gravity points to create the Bouguer gravity anomaly map (Figure 7). The gravity data were merged from a variety of surveys and cover the US and the border region. Average error for this data set ranges from 0.05 to $2 \mathrm{mGal}$ (Al-Douri, personal communication, 2009). Reference [29] of the US Geological Survey using a digital elevation model calculated terrain corrections and a technique based on the approach of [30]. A Bouguer gravity correction was made using $2670 \mathrm{~kg} / \mathrm{m}^{3}$ as the reduction density. Aeromagnetic data were obtained from the US Geological Survey with a grid spacing of $1 \mathrm{~km}$ [31]. We used 112,436 aeromagnetic measurement points to create the magnetic anomaly map (Figure 8). We used Montage Oasis soft ware for contouring and Adobe illustrate for final production. Both maps were projected using UTM projection.

\section{Model Development}

We created a crustal scale model (Figure 9) to explore the deep structures of the active and fossil spreading centers using the unfiltered Bouguer gravity and magnetic anomaly maps with the receiver function analysis. We divided our targeted features into "active" and "fossil" spreading centers based on the amount (magnitude and frequency) of seismic activity corresponding with known faults and the style of the potential field anomaly. That is, we expect high amplitude Bouguer gravity anomalies to correspond to the rifts because of the thin crust and shallow Moho which is typical for rift settings.

\section{Crustal Model}

The starting point for our model was to incorporate the depth to the Moho that was determined from the receiver

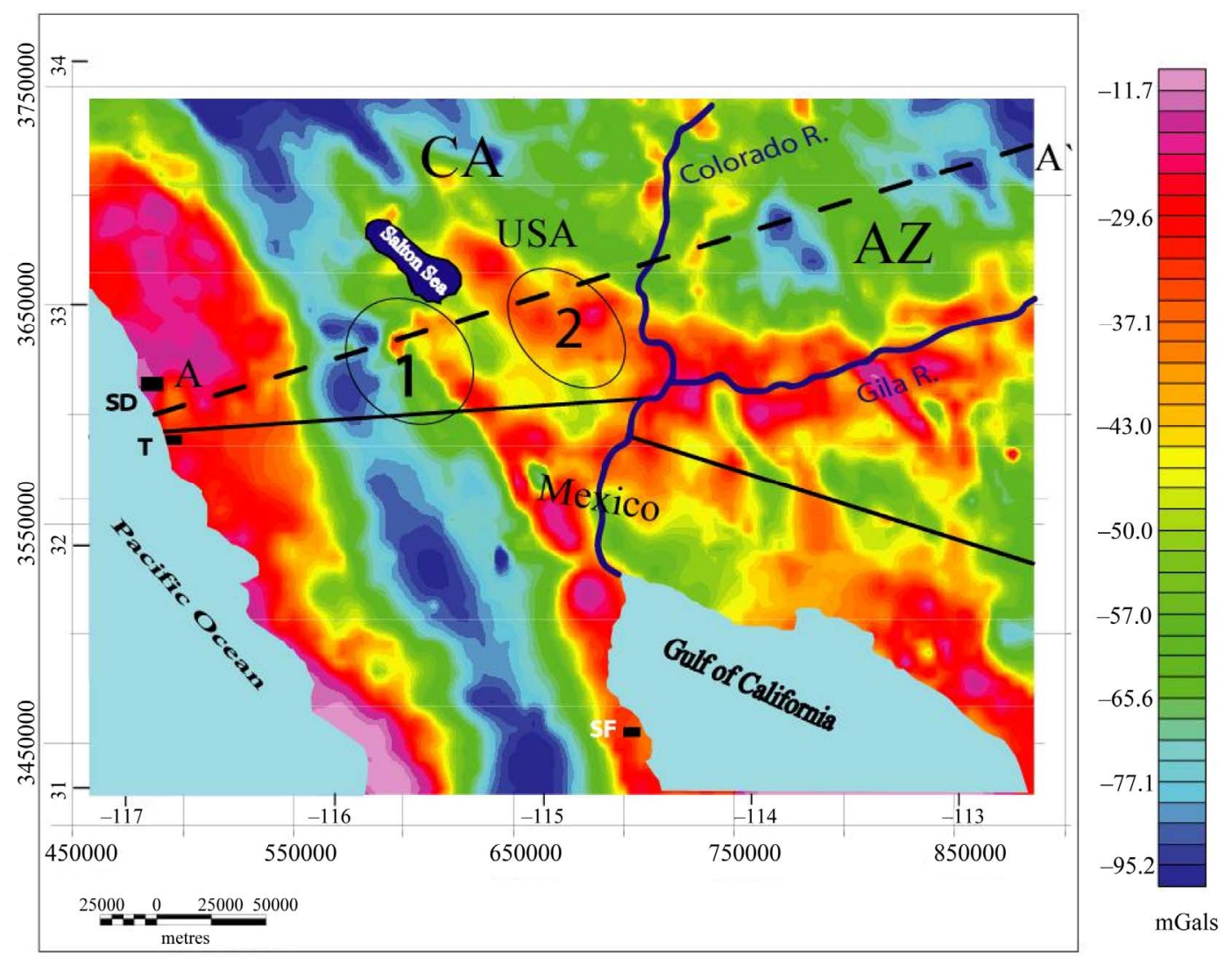

Figure 7. Bouguer gravity anomaly map of the Salton Trough area. Fossil spreading centers and active spreading centers are gravity high related to basaltic volcanism of Salton Buttes, and due to the presence of shallow Moho and magmatic intrusion. Dashed line A-A' shows the location of the crustal profile. Circle labeled as 1 shows the approximate location of the active spreading centers; circle 2 shows the approximate location of the fossil spreading centers. SD: San Diego; T: Tijuana; SF: San Felipe. 


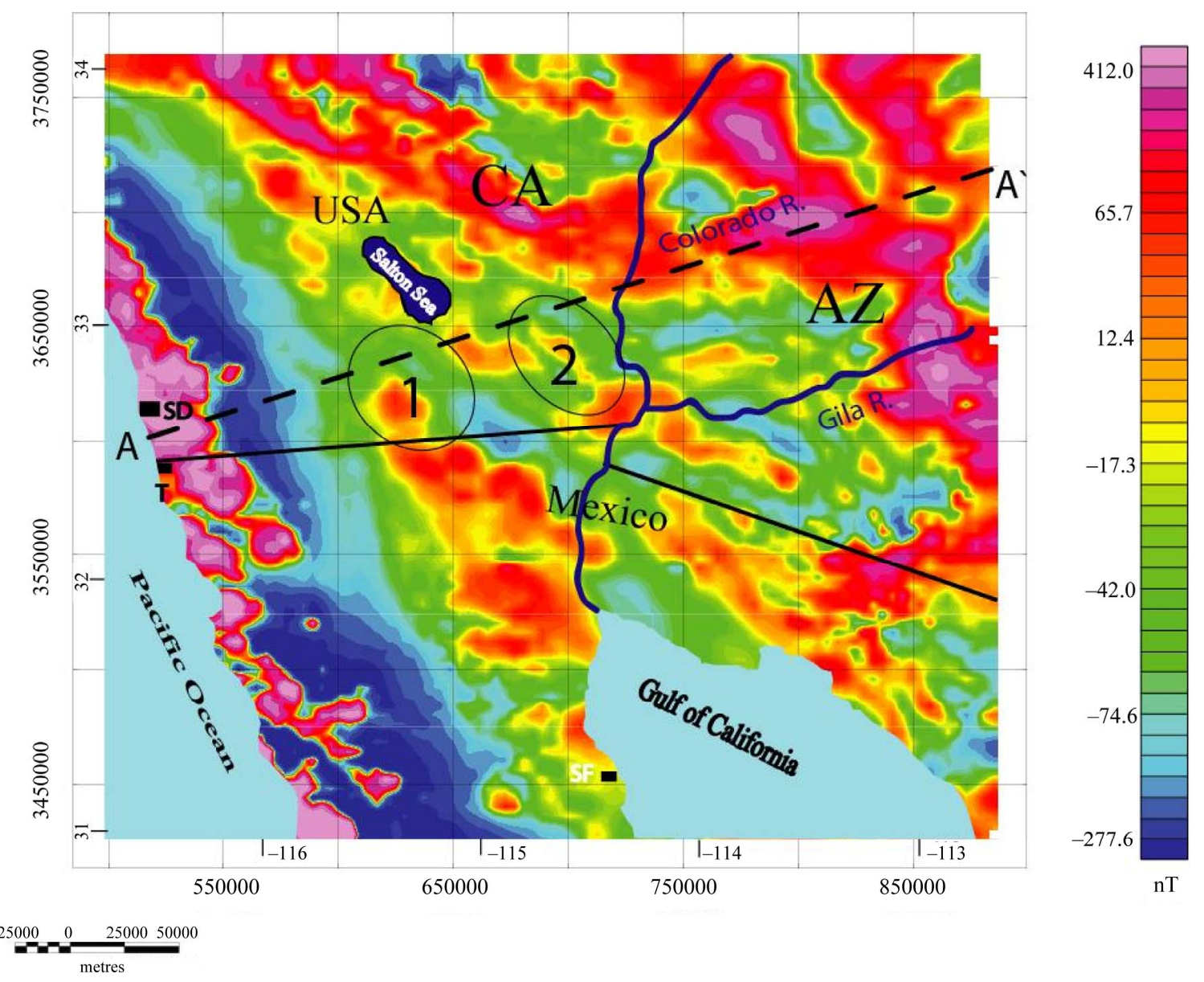

Figure 8. Magnetic anomaly map of the Salton Trough. Fossil spreading centers are magnetic medium to high related to basaltic rocks; active spreading centers are magnetic low associated with the fluids in the upper crust. Dashed line A-A' shows the location of the crustal profile. Circle labeled as 1 shows the approximate location of the active spreading centers; circle 2 shows the approximate location of the fossil spreading centers. SD: San Diego; T: Tijuana; SF: San Felipe.

function analysis and the densities for the upper, middle, lower crust, and upper mantle from previous studies [7,12,32]. Magnetic susceptibilities estimated from [33].

The density (D) for the upper crust (sediments and metasedimenatry composition) ranges from 2500 to 2600 $\mathrm{kg} / \mathrm{m}^{3}$, while magnetic susceptibility (S) ranges from 0.002 to 0.007 , density of the middle crust is $2750 \mathrm{~kg} / \mathrm{m}^{3}$, and $(\mathrm{S})$ is 0.065 and mostly quartzofeldspathic composition, density of the lower crust is $2950 \mathrm{~kg} / \mathrm{m}^{3}$ (gabbroic composition), and (S) is 0.004 . Density of the magmatic body is $3100 \mathrm{~kg} / \mathrm{m}^{3}$, its magnetic susceptibility is 0.0 , and the mantle density is $3300 \mathrm{~kg} / \mathrm{m}^{3}$ with a magnetic susceptibility of 0.0 .

The profile (A-A') is about $450 \mathrm{~km}$ long, and crosses the central part of the study area (see Figure 7 for profile location). The depth to the Moho, determined from the receiver function, varies from $38 \mathrm{~km}$ at the starting point (A), decreases to $26 \mathrm{~km}$ southwest of the Salton Sea, and increases to $32 \mathrm{~km}$ at the end point ( $\left.\mathrm{A}^{\prime}\right)$ of the model. Magmatic intrusion is modeled at a depth of about $20 \mathrm{~km}$ to the southwest of Salton Sea as shown by the crustal model (Figure 9). That intrusion extends for $70 \mathrm{~km}$ in SW-NE direction as interpreted from the model. Magmatic intrusion released fluids that promote seismic activity in the active spreading centers.

\section{Discussion}

We used several data sets to interpret seismic activity in the active spreading centers of Salton Trough. Table 4 summarizes the differences in observations and models between the active and fossil (inactive) spreading centers. We incorporate receiver function analysis with gravity and magnetic data to create a subsurface crustal scale model that reveals magmatic intrusion underlies the active spreading centers. $V p / V s$ ratios are high in the area where magmatic intrusion presents and indicates partial melt in the lower crust; $b$-values are high in these same areas and indicate fluids in the upper crust.

We interpret upper crustal seismicity within the active spreading centers to promote by fluids ex-solved from 


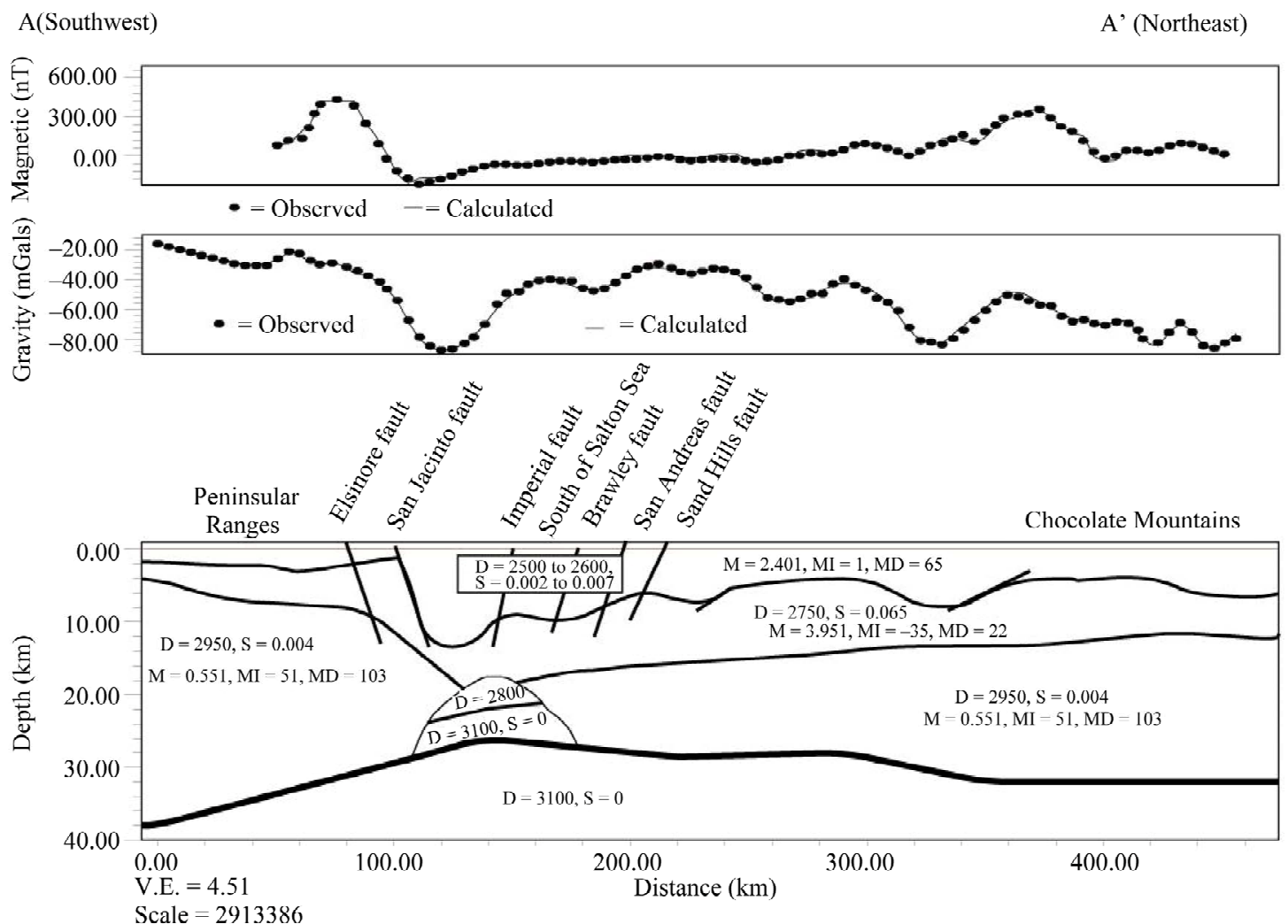

Figure 9. Interpretative model for gravity and aeromagnetic data profile A-A' (Central region of Salton Trough). This model is about $\sim 450 \mathrm{~km}$ long, covers the central part of the study area. The depth to the Moho, according to the receiver functions, varies from $25 \mathrm{~km}$ at the central point of the model south of Salton Sea [D = Density $\left(\mathrm{kg} / \mathrm{m}^{3}\right), \mathrm{S}=$ Susceptibility $($ dimensionless), $\mathrm{M}=$ Magnetization (A/m), MI = Magnetic inclination (degree), $\mathrm{MD}=$ Magnetic declination (degree)]

Table 4. Summary of the major differences between active and fossil spreading centers of the Salton Trough as extracted from incorporating different data sets.

\begin{tabular}{ccc}
\hline Compared characteristics & Active spreading centers & Fossil spreading centers \\
\hline Depth to Moho & Shallow Moho (thin crust) & Deeper Moho (thick crust) \\
$V p / V s$ & High in lower rust & Low in the lower crust \\
$b$-Values & High $b$-values & Low $b$-values \\
Gravity anomalies & High gravity amplitudes & Low gravity amplitudes \\
Magnetic anomaly & Low magnetic amplitude & High magnetic amplitude \\
Seismic activity & Seismically active & No seismic activity \\
Magmatic underplating & Magmatic body at depth of $20 \mathrm{~km}$ & No evidence for any magmatic intrusions \\
\hline
\end{tabular}

the magmatic intrusion that underlies the spreading centers at a depth of about $20 \mathrm{~km}$ because cyclic fluid pore pressure increase weakens faults [34]. Earthquake activity in the lower crust has been identified at several rifts (e.g. Taupo Volcanic Zone, New Zealand, [5]) suggesting the possibility of fluid involvement. Both seismicity and tomography suggest that in order for these lower crustal events to occur, fluids needed, as well as a rheologically strong lower crust that restricts these fluids to its base. The strength of the crust is governed by strain rate, temperature and rock composition as well as pore fluid pressure [5].

The locations of the active spreading centers are characterized by high amplitude gravity anomalies because the crust is thin and the Moho is shallow beneath active spreading centers according to our receiver function analysis (Figures 3 and 4). Low gravity anomaly observed to the west and south of the Salton Sea, we relate this low anomaly to the existence of fluids or partial melt. We assume the crust is gabbroic in composition, consistent with our model density of $2950 \mathrm{~kg} / \mathrm{m}^{3}$. This composition could provide the strong lower crust that restricts 
fluids to its base. The active spreading centers are characterized by a low magnetic anomaly inferred to be the response from molten material and/or fluids. In contrast, high amplitude magnetic anomalies prevail in the fossil spreading centers due to the magnetization of cooled gabbro and less fluid in the crust.

Several lines of evidence indicate the role of fluid involvement in seismic activity within the active spreading centers of the Salton Trough. High $V p / V s$ to the south and southwest of the Salton Sea provide evidence for such activity (Figure 4).

The crustal scale model suggests a partially molten, mafic intrusion underlies the location of the active spreading centers (Figure 9). We interpret the fluids to be derived from that magma intrusion. Our model also shows a doming of the Moho beneath the spreading centers (between San Jacinto and San Andreas faults, Figure 9) which is suggested to results from magmatic activity and intrusion in the lower crust and upper mantle. Reference [35] concluded that the regional upper mantle is very heterogeneous with the greatest amplitude of velocity and $V p / V s$ perturbations in the upper $200 \mathrm{~km}$ and mantle structure that correlate spatially with major physiographic provinces of southern California.

The largest low velocity, high $V p / V s$ anomaly is found beneath the Salton Trough and is attributed to relatively high partial melt in the asthenosphere resulting in lithospheric thinning. Reference [4] concluded from the magnitudes of $V p, V s$, and $V p / V s$ perturbations, and knowledge of regional $1-\mathrm{D}$ velocity and attenuation, that the asthenosphere contains up to $1 \%$ partial melt extending to depths of $150-200 \mathrm{~km}$.

$b$-values from frequency-magnitude plots for southwest California are high. According to [25,26], areas of high $b$-values are attributed to the presence of a high thermal gradient due to the emplacement of magmatic fluids [27,28]. Earthquakes occur on strike slip and/or normal faults in these areas. The lack of coincidence between the epicenteral area of seismic activity and the surface outlet of sub-crustal fluids suggest that the escaping fluids do not follow vertical pathway on moving from their deep source to the surface [36]. Pressurized fluids can escape from their source along high permeability pathways in the upper crust [37].

\section{Conclusion}

Seismic activity is restricted to the active spreading centers of the Brawly, Cerro Prieto, Imperial, Elsinore, and San Jacinto fault zones, these are strike-slip faults that extend from $15 \mathrm{~km}$ (Brawley fault) to $210 \mathrm{~km}$ (San Jacinto fault zone) in the active spreading centers of the Salton Trough rift (Figure 2). Spreading is limited or absent in the fossil spreading centers at the Sand Hill and
Algodones faults (Figure 2). We associate seismic activity with the presence of a magmatic intrusion beneath the active spreading centers and with fluids derived from this intrusion. Several lines of evidence support the existence of magma intrusion and fluids: 1) low velocity and high $V p / V s$ ratios in the lower crust as shown by tomography and receiver function analysis; 2) low amplitude magnetic anomaly in the location of active spreading centers attributed to the fluids and/or melts; and 3) a high amplitude gravity anomaly that underlies the active spreading characteristics of the inferred magma intrusion can be recognized over a distance of $70 \mathrm{~km}$ in a NE-SW direction along the fault zones of the active spreading centers (Figure 9). Frequency-magnitude distribution $b$-values are high in southwest California including the study area; high $b$-values are attributed to high thermal gradient due to the emplacement of magmatic fluids.

\section{Acknowledgements}

We would like to thank, Dr. Terry Pavlis, Dr. William Cornell and Dr. Vladik Kreinovich for helpful discussions. We would like also to thank Carlos Montana for the technical support. The work partially supported by NSF HRD 0734825 Cyber-ShARE Center of Excellence.

\section{REFERENCES}

[1] M. Becken, O. Ritter, S. Park, P. Bedrosian, U. Weckmann and M. Weber, "A Deep Crustal Fluid Channel into the San Andreas Fault System near Park Field, California," Geophysical Journal International, Vol. 173, No. 2, 2008. pp. 718-732.

[2] S. Kirby, K. Wang and T. Brocher, "A Possible Deep, Long-Term Source for Water in the Northern San Andreas Fault System: A Ghost of Cascadia Subduction Past," EOS Transactions of AGU, Vol. 83, No. 47, 2002.

[3] B. Kennedy, Y. Kharaka, W. Evans, A. Ellwood, J. DePaolo, G. Thordsen and R. Mariner, "Mantle Fluids in the San Andreas Fault System California," Science, Vol. 278, No. 5341, 1997, pp. 1278-1280. doi:10.1126/science.278.5341.1278

[4] M. Zoback, "Strength of the San Andreas," Nature, Vol. 44, 2000, pp. 31-32. doi:10.1038/35011181

[5] M. Reyners, D. Eberhart-Phillips and G. Stuart, "The Role of Fluids in Lower-Crustal Earthquakes near Continental Rifts," Nature, Vol. 446, No. 7139, 2007, pp. 1075-1078.

[6] T. Seno and A. Saito, "A Recent East African Earthquakes in the Lower Crust," Earth Planet Science Letters, Vol. 121, No. 1-2, 1994, pp. 125-136. doi:10.1016/0012-821X(94)90036-1

[7] T. Parsons, J. McCarthy and G. Thompson, "Very Different Crustal Response to Extreme Extension in the Southern Basin and Range and Colorado Plateau Transition," In: M. C. Erskine, J. E. Faulds, J. M. Bartley and P. D. Rowley, Eds., American Association of Petroleum Ge- 
ologists Pacific Section Guidebook, GB 78, 2001, pp. 291-304.

[8] S. Larsen and R. Reilinger, "Age Constraints for the Present Fault Configuration in the Imperial Valley, California: Evidence for Northwestward Propagation of the Gulf of California Rift System," Journal of Geophysical Research, Vol. 96, No. B6, 1991, pp. 10339-10446. doi:10.1029/91JB00618

[9] P. Lonsdale, "Geological and Tectonic History of the Gulf of California," In: D. Wintere, M. Husson and R. Decker, Eds., The Eastern Pacific Ocean and Hawaii, Geological Society of America, 1989, pp. 499-521.

[10] W. Elders, R. Rex, T. Mediva, P. Robimson and S. Biehler, "Crustal Spreading in Southern California," Science, Vol. 178, No. 4056, 1972, pp. 15-24. doi:10.1126/science.178.4056.15

[11] J. Stock and K. Hodges, "Transfer of Baja California to the Pacific Plate," Tectonics, Vol. 8, No. 1, 1989, pp. 99115.

[12] T. Parsons and J. McCarthy, "Crustal and Upper Mantle Velocity Structure of the Salton Trough Southeast California," Tectonics, Vol. 15, No. 2, 1996, pp. 456-471. doi:10.1029/95TC02616

[13] A. Lachenbruch, J. Sass and S. Galanis, "Heat Flow in Southernmost California and the Region of the Salton Trough," Journal of Geophysical Research, Vol. 90, No. B8, 1985, pp. 6709-6736. doi:10.1029/JB090iB08p06709

[14] C. Ammon, G. Randall and G. Zandt, "On the Nonuniqueness of Receiver Function Inversions," Journal of Geophysical Research, Vol. 95, No. B10, 1990, pp. 1530315318. doi:10.1029/JB095iB10p15303

[15] L. Zhu and H. Kanamori, "Moho Depth Variation in Southern California from Teleseimic Receiver Functions," Journal of Geophysical Research, Vol. 105, No. B2, 2000, pp. 2969-2980.

[16] L. Ligorria and C. Ammon, "Iterative Deconvolution and Receiver Function Estimation," Bulletin of Seismological Society of America, Vol. 89, No. 5, 1999, pp. 1395-1400.

[17] L. Zhu, "Estimation of Crustal Thickness and $V p / V s$ Ratio beneath the Tibetan Plateau from Teleseismic Converted Waves," EOS Transactions of $A G U$, Vol. 74, No. 16, 1993.

[18] G. Zandt, S. Myers and T. Wallace, "Crust and Mantle Structure across the Basin and Range Colorado Plateau Boundary at $37^{\circ} \mathrm{N}$ Latitude and Implication for Cenozoic Extensional Mechanism," Journal of Geophysical Research, Vol. 100, No. B6, 1995, pp. 10529-10548.

[19] G. Zandt and C. Ammon, "Continental Crust Composition Constrained by Measurements of Crustal Poisson Ratio," Nature, Vol. 374, 1995, pp. 152-154.

[20] L. Serpa, "Structural Styles across an Extensional Orogen; Results from the COCORP Mojave and Death Valley Seismic Transects," In: B. P. Wernicke, Ed., Basin and Range Extensional Tectonics near the Latitude of Las Vegas, Nevada, Geological Society of America Memoir 176, Boulder, 1990, pp. 335-344.

[21] S. Cahng and C. Baag, "Moho Depth and Crustal Vp/Vs Variation in Southern Korea from Teleseismic Receiver
Functions: Implication for Tectonic Affinity between the Korean Peninsula and China," Bulletin of the Seismological Society of America, Vol. 97, No. 5, 2007, pp. 1621-1631. doi:10.1785/0120050264

[22] T. Nakajima, A. Matsuzawa, A. Hasegawa and D. Zaho, "Three Dimensional Structure of $V p, V s$, and $V p / V s$ Beneath Northeastern Japan: Implications for Arc Magmatism and Fluids," Journal of Geophysical Research, Vol. 106, 2001, pp. 21843-21857. doi:10.1029/2000JB000008

[23] M. Matsubara, N. Hirata, S. Sakai and I. Kawasaki, "A Low Velocity Zone Beneath the Hida Mountains Derived from Dense Array Observation and Tomographic Method," Earth Planets Space, Vol. 52, No. 3, 2000, pp. 143-154.

[24] D. Schorlemmer, S. Wiemer and M. Wyss, "Variations in Earthquake-Size Distribution across Different Stress Regimes," Nature, Vol. 437, 2005, pp. 539-542.

[25] L. Knopoff, "The Magnitude Distribution of Declustered Earthquakes in Southern California," PNAS, Vol. 97, No. 22, 2000, pp. 11880-11884. doi:10.1073/pnas.190241297

[26] J. Mori and R. Abercrombie, "Depth Dependence of Earthquake Frequency-Magnitude Distribution in California: Implication for Rupture Initiation," Journal of Geophysical Research, Vol. 102, No. B7, 1997, pp. 1508115090. doi:10.1029/97JB01356

[27] J. Farrell, S. Husen and R. Smith, "Earthquake Swarm and $b$-Value Characterization of the Yellowstone Volcano-Tectonic System," Journal of Volcanology and Geothermal Research, Vol. 188, 2009, pp. 260-276. doi:10.1016/j.jvolgeores.2009.08.008

[28] C. Singh and R. Chadha, "Variations in the FrequencyMagnitude Distribution of Earthquakes with Depth in the Koyna-Warna Region, India," Journal of Asian Earth Sciences, Vol. 39, 2010, pp. 331-334. doi:10.1016/j.jseaes.2010.03.014

[29] W. Webring, "MINC, a Gridding Program Based on Minimum Curvature," US Geological Survey Open-File Report, US Geological Survey, Denver, 1982, pp. 811224.

[30] D. Plouff, "Preliminary Documentation for a FORTRAN Program to Compute Gravity Terrain Corrections Based on Topography Digitized on a Geographic Grid," US Geological Survey Open File Report 77-535, 1977, p. 45.

[31] V. Bankey, A. Cuevas, D. Daniels, C. Finn, I. Hernandez, P. Hill, R. Kucks, W. Miles, M. Pilkington, C. Roberts, W. Roest, V. Rystrom, S. Shearer, S., Snyder, R. Sweeney, J. Velez, J. Phillips and D. Ravat, "Digital Data Grids for the Magnetic Anomaly187 Map of North America," US Geological Survey Open-File Report 02-414, 2002.

[32] G. Fuis, W. Mooney, J. Healey, G. McMechan and W. Lutter, "A Seismic Refraction Survey of the Imperial Valley Region, California," Journal of Geophysical Research, Vol. 89, No. B2, 1984, pp. 1165-1189. doi:10.1029/JB089iB02p01165

[33] V. Langenheim, R. Jachen, J. Matti, E. Hauksson, D. Morton and A. Christensen, "Geophysical Evidence for Wedging in the San Gergonio Pass Structural Knot, Southern San Andreas Fault Zone, Southern California," GSA Bulletin, Vol. 117, 2005, pp. 1554-1572. 


\section{doi:10.1130/B25760.1}

[34] R. Sibson, "Fluid Involvement in Normal Faulting," Journal of Geodynamics, Vol. 29, No. 3, 2000, pp. 469-499. doi:10.1016/S0264-3707(99)00042-3

[35] B. Schmandt and E. Humphreys, "Seismic Heterogeneity and Small-Scale Convection in the Southern California Upper Mantle," Geochemistry Geophysics Geosystems, Vol. 11, 2010, Article ID: Q05004.

[36] K. Brauer, H. Kampf, G. Strauch and S. Weise, "Isotopic Evidence $\left({ }^{3} \mathrm{He} /{ }^{4} \mathrm{He},{ }^{13} \mathrm{CCO}_{2}\right)$ of Fluid Triggered Intraplate

\section{Websites:}

NSF "Earthscope" 2003. June 182006.

$<$ http//www.earthscope.org/>

NSF "Earthscope Automated Receivers Survey (EARS)"

2003. June 18 2006. http://www.ears.iris.washington.edu
Seismicity," Journal of Geophysical Research, Vol. 108, No. 2, 2003.

[37] S. Giammanco, M. Palano, A. Scaltrio, L. Scarfi and F. Sortion, "Possible Role of Fluid Overpressure in the Generation of Earthquake Swarms in Active Tectonic Areas: The Case of the Peloritani Mts. (Sicily, Italy)," Journal of Volcanology and Geothermal Research, Vol. 178, No. 4, 2008, pp. 795-806. doi:10.1016/j.jvolgeores.2008.09.005

UTEP "Pan-American Center for Earth and Environmental Studies" 19-Jul-2005. Aug-20-2006.

http://www.research.utep.edu/paces

Southern California Earthquake Data Center (SCEDC), 2003, April 2011. http://www.data.scec.org/index.html 